\title{
POLA PENYEDIAAN DAN POTENSI HIJAUAN DI KAWASAN INDUSTRI KECAMATAN CITEUREUP KABUPATEN BOGOR
}

\author{
Setiana M.A., Ikmahwati S., Yakin A. dan Prihantoro I. \\ Departemen Ilmu Nutrisi dan Teknologi Pakan, Fakultas Peternakan Institut Pertanian Bogor \\ J. Agatis Kampus IPB Dramaga Bogor 16680 - Indonesia \\ e-mail : massetiana@yahoo.com
}

\begin{abstract}
ABSTRAK
Penelitian ini bertujuan untuk mengidentifikasi dan menganalisis pola penyediaan dan potensi hijauan di berbagai wilayah Kecamatan Citeureup Kabupaten Bogor. Penelitian ini dilakukan dengan mengidentifikasi enam desa yang terletak di daerah padat industri dan padat penduduk dan satu desa yang masih memiliki hijauan yang relatif banyak. Analisis yang dilakukan adalah analisis komposisi botani dengan mengidentifikasi semua jenis hijauannya, analisis kapasitas tampung, pengukuran $\mathrm{pH}$ tanah dan menganalisis kandungan logam $\mathrm{Pb}$ pada hijauan, air, dan tanah pada semua desa yang digunakan. Hasil didapatkan bahwa daerah yang pembangunan industrinya tinggi dan terdapat banyak pabrik sangat mempengaruhi proporsi dan jenis hijauan sehingga potensi hijauannya kurang. Pola penyediaan hijauan desa ini, hijauannya cenderung didapatkan dari luar (cut and carry) dan potensi hijauannya cukup rendah.
\end{abstract}

Kata kunci: Timbal (Pb), industri, hijauan, kapasitas tampung.

\begin{abstract}
The aims of this research was to identify and analyze potential forage in different area of Citeureup subdistrict, Bogor regency. This research done by identifying the six villages located in densely populated area industry and one village still have relatively much forage. Analysis of botanical composition is selected to identify the forage variety, capacity analysis, measurement of soil $\mathrm{pH}$ and analyze the lead $(\mathrm{Pb})$ content in forage, water and soil. The results is area that has great development in industry affect proportion and forage variety and has forage potential less. The pattern of the provision of forage for a village that has great development in industry, tending to obtained from outside the village (cut and carry). This is because of the metal lead high on the ground in the village so that the growth of forage disturbed and the quality of forage doubtful.
\end{abstract}

Keywords: Lead (Pb), industry, forage, and carrying capacity.

\section{PENDAHULUAN}

Hijauan merupakan sumber bahan pakan yang utama bagi ternak ruminansia. Hijauan makanan ternak di Indonesia terutama dalam peternakan rakyat, diperoleh dari berbagai sumber antara lain, pematang sawah, tepi hutan, perkebunan, sisa hasil pertanian, dan juga sering kali di tepi jalan yang mungkin hijauan tercemar logam berat akibat dari polusi. Logam berat dapat terakumulasi dalam jumlah yang cukup besar pada tanaman seperti padi, rumput, dan beberapa jenis leguminosa untuk pakan ternak. Salah satu logam berat yang seringkali mencemari lingkungan adalah logam timbal $(\mathrm{Pb})$. Timbal merupakan logam berat yang sangat beracun, dan sebagian besar diakumulasi oleh organ tanaman, yaitu daun, batang, akar dan umbi- umbian. Beberapa faktor yang menyebabkan kontaminasi logam berat pada lingkungan antara lain: kondisi geologi tanah, kondisi air, kontaminan logam berat tertentu yang berasal dari industry. Kecamatan Citeureup merupakan kawasan industri yang juga sebagian besar penduduknya bermata pencaharian sebagai peternak skala kecil. Pembanguan industri yang tinggi menyebabkan keterbatasan hijauan. Tujuan penelitian ini yaitu mengidentifikasi dan menganalisis pola penyediaan dan potensi hijauan di kawasan industri Kecamatan Citeureup, Kabupaten Bogor.

\section{METODE PENELITIAN}

Penelitian ini dilaksanakan pada bulan Oktober hingga Desember Tahun 2014 di tujuh desa di Kecamatan Citeureup, Kabupaten Bogor, yaitu Desa Citeureup, Desa Tarikolot, Desa Puspasari, Desa Puspanegara, Desa Karang Asam Barat, Desa Karang 
Asam Timur, dan Desa Hambalang. Metode penelitian yang digunakan yaitu observasi langsung di lapang terhadap hijauan pakan. Pada setiap desa dilakukan identifikasi 3 blok (tiga tempat sebagai ulangan) yang mana satu blok itu terdiri empat titik yang diambil sampel hijauan dan tanahnya, serta melakukan wawancara langsung pada peternak kambing jawa, dimana ternak kambing jawa di Kecamatan Citeureup sangat mendominasi dibanding ternak ruminansia lainnya.

Parameter yang diamati dalam penelitian ini adalah komposisi botani hijauan pakan di lapang dan kandang, identifikasi cemaran logam timbal $(\mathrm{Pb})$ pada hijauan, $\mathrm{pH}$ tanah, dan kapasitas tampung lahan, serta data pendukung lainnya (data sekunder) yang berhubungan dengan penelitian ini, seperti data dari BPS Kabupaten Bogor. Analisis data yang digunakan adalah analisis deskriptif (hasil wawancara peternak, gambaran keragaman dan pola penyediaan hijauan pakan di lokasi), analisis komposisi botani (menggunakan metode "Dry Weight Rank", analisis kapasitas tampung dengan menggunakan kuadran ukuran $0,5 \times 0,5$ meter untuk mengetahui produksi BK hijauan setiap cuplikan yang diambil, analisis kualitas hijauan (analisis proksimat), analisis kandungan timbal $(\mathrm{Pb})$ pada hijauan, tanah dan air dengan menggunakan alat Atomic Absorption Spectrophotometer (AAS), serta dilakukan pembuatan herbarium pada jenis hijauan pakan yang belum bisa diidentifikasi langsung pada komposisi botani di setiap lokasi.

\section{HASIL DAN PEMBAHASAN}

Kecamatan Citeureup merupakan kecamatan yang pembangunan industrinya cukup tinggi di Kabupaten Bogor. Kecamatan Citeureup memiliki 14 desa dengan 6 desa yang penggunaan lahan pertaniannya kurang seperti Desa Citeureup, Tarikolot, Puspasari, Puspanegara, Karang Asem Timur, dan Karang Asem Barat, selain itu keenam desa tersebut merupakan desa yang padat industry dan padat penduduk. Desa Hambalang kondisinya sangat berbeda jika dibandingkan dengan keenam desa tersebut, lahan pertaniannya tersedia cukup luas. Ketersediaan lahan yang cukup luas ini, diharapkan Desa Hambalang menjadi pembanding dalam ketersediaan hijauan.

\section{Analisis Komposisi Botani}

Hasil uji sidik ragam Rancangan Acak Kelompok (RAK) proporsi rumput, legum, dan rumbah untuk tujuh desa yang diamati tidak berpengaruh nyata ( $\mathrm{P}>$ 0.05) terhadap komposisi hijauan padang penggembalaan pada desa di Kecamatan Citeureup. Hasil analisis komposisi botani menunjukkan bahwa kualitas padang penggembalaan di tujuh desa lokasi penelitian tersebut kurang ideal. Menurut Crowder dan Cheeda (1982), kualitas padang penggembalaan tergolong baik apabila proporsi antara rumput, legum, dan rumbah (diluar rumputan dan kacangan) sebesar $3: 2: 0$ atau 60\% rumput, 40\% legum, dan $0 \%$ rumbah. Berdasarkan tabel 1, proporsi dari hijauan sangat beragam, dimana rumput sangat mendominasi, diikuti dengan rumbah dan legum. Ketersediaan legum di tujuh desa tersebut sangat sedikit, seperti di Desa Karang Asem Timur yang mencapai 1.88\%, tetapi untuk Desa Hambalang dan Desa Puspasari ketersediaannya relatif lebih tinggi yaitu $20.37 \%$ dan $15.14 \%$. Desa Hambalang dan Desa Puspasari menunjukkan bahwa proporsi ketersediaan hijauannya sangat beragam.

Tabel 1. Komposisi hijauan di padang penggembalaan

\begin{tabular}{lccc}
\hline \multirow{2}{*}{\multicolumn{1}{c}{ Desa }} & \multicolumn{3}{c}{ Hijauan (\%) } \\
\cline { 2 - 4 } & Rumput & Legum & Rumbah \\
\hline Hambalang & $51.57 \pm 6.60$ & $20.37 \pm 10.93$ & $28.06 \pm 15.31$ \\
Citeureup & $65.17 \pm 2.30$ & $3.67 \pm 0.67$ & $31.01 \pm 2.23$ \\
Puspasari & $56.31 \pm 4.86$ & $15.14 \pm 9.73$ & $25.55 \pm 6.22$ \\
Puspanegara & $69.36 \pm 1.01$ & $3.32 \pm 0.30$ & $27.32 \pm 0.73$ \\
Tarikolot & $66.93 \pm 3.94$ & $9.53 \pm 6.18$ & $23.54 \pm 2.70$ \\
Karang Asem Barat & $68.83 \pm 4.64$ & $6.57 \pm 5.84$ & $24.61 \pm 1.97$ \\
Karang Asem Timur & $58.73 \pm 4.57$ & $1.88 \pm 0.46$ & $39.39 \pm 4.19$ \\
\hline
\end{tabular}

Tabel 2. Komposisi hijauan di kandang

\begin{tabular}{lccc}
\hline \multirow{2}{*}{ Desa } & \multicolumn{3}{c}{ Hijauan (\%) } \\
\cline { 2 - 4 } & Rumput & Legum & Rumbah \\
\hline Hambalang & $26.14 \pm 12.64$ & $55.98 \pm 5.52$ & $17.89 \pm 7.65$ \\
Citeureup & $25.94 \pm 22.44$ & $60.80 \pm 22.22$ & $13.27 \pm 0.22$ \\
Puspasari & $79.94 \pm 6.98$ & $1.43 \pm 0.64$ & $18.64 \pm 6.35$ \\
Tarikolot & $19.69 \pm 2.89$ & $71.84 \pm 2.39$ & $8.47 \pm 0.50$ \\
\hline
\end{tabular}

Berdasarkan hasil pengamatan pada tabel 2, proporsi hijauan yang diberikan pada ternak kambing di Desa Hambalang, Citeureup, dan Tarikolot relatif beragam, komposisi legum sangat mendominasi dibandingkan rumput dan rumbah. Pada Desa Puspasari, hijauan yang diberikan pada ternak kambing didominasi oleh rumput, pemberian legum sangat kecil, yaitu 1.43\%, hal ini berbanding terbalik dengan komposisi legum di padang penggembalaan di Desa Puspasari, yaitu $15.14 \%$. Data tersebut menunjukkan bahwa legum yang ada di Desa Puspasari tidak termanfaatkan secara optimal. Hal ini disebabkan oleh kurangnya pengetahuan peternak tentang jenis hijauan pakan ternak terutama ternak kambing, dimana peternak di Desa Puspasari ini bekerja sebagai buruh, jadi kurang memahami jenis hijauan pakan apa yang lebih disukai oleh ternak kambing. Sedangkan di Desa Hambalang, Citeureup, dan Tarikolot, beternak merupakan pekerjaan utama peternak, sehingga hijauan yang diberikan pada ternak 
relatif beragam. Kapasitas tampung lahan padang penggembalaan di Kecamatan Citeureup berkisar 1.02 - 1.93 ST per ha, tabel 3 menunjukkan bahwa Desa Citeureup memiliki nilai kapasitas tampung ternak tertinggi, yaitu 1.93, sedangkan nilai terendah terdapat pada Desa Hambalang. Menurut Sinaga (2009), bahwa daya tampung padang penggembalaan tergantung kemiringan lahan, jarak dengan sumber air, kecepatan pertumbuhan atau produksi tanaman pakan, kerusakan lahan, ketersediaan hijauan yang dapat dikonsumsi, dan keadaan ekologi padang penggembalaan. Peternak di Desa Citeureup cenderung melakukan perawatan pada padang penggembalaan terutama pada hijauan pakan unggul dengan cara pembasmian gulma dan penambahan pupuk kandang, sehingga produksinya tinggi.

Tabel 3. Kapasitas Tampung Padang Gembala

\begin{tabular}{lc}
\hline \multicolumn{1}{c}{ Desa } & Kapasitas Tampung (ST ha-1) \\
\hline Hambalang & $1.02 \pm 0.09$ \\
Citeureup & $1.93 \pm 0.21$ \\
Puspasari & $1.57 \pm 0.06$ \\
Puspanegara & $1.56 \pm 0.40$ \\
Tarikolot & $1.33 \pm 0.21$ \\
Karang Asem Barat & $1.46 \pm 0.29$ \\
Karang Asem Timur & $1.73 \pm 0.32$ \\
\hline
\end{tabular}

Kondisi pH tanah berdasarkan hasil analisis di Kecamatan Citeureup rata-rata masuk dalam kategori masam, yaitu berkisar 4.0 - 6.7, Desa Karang Asem Timur mempunyai $\mathrm{pH}$ tanah 6.7 dimana tanahnya masih tergolong netral atau normal. Setiap tanaman membutuhkan $\mathrm{pH}$ yang spesifik agar pertumbuhan tanamannya optimal. pH tanah yang ideal untuk semua jenis tanaman, perkebunanan, dan hortikultura di Indonesia berkisar 6 - 7 (Pairunan et al. 1985). Rendahnya nilai $\mathrm{pH}$ tanah pada enam desa lokasi penelitian ini dimungkinkan adanya cemaran polusi baik dari transportasi maupun industri yang ada, terutama cemaran logam timbal $(\mathrm{Pb})$ yang dapat mengganggu siklus hara dalam tanah. Hasil penelitian (tabel 4) menunjukkan bahwa tanah dan air di semua lokasi penelitian dinyatakan tercemar logam timbal $(\mathrm{Pb})$, konsentrasi timbal dalam tanah berkisar 14.520 ppm - 25.102 ppm dan air berkisar 0.034 ppm - 0.12 $\mathrm{ppm}$. Standar normal kandungan timbal $(\mathrm{Pb})$ pada tanah dan air adalah maksimal $10 \mathrm{ppm}$ dan 0.001 - 0.01 ppm. Desa Karang Asem Timur cemarannya lebih sedikit dibanding desa lainnya, karena $\mathrm{pH}$ tanah di desa tersebut masih dalam kisaran normal. Konsentrasi timbal $(\mathrm{Pb})$ pada hijauan menunjukkan hasil yang normal atau aman bagi ternak, yaitu berkisar $0.539 \mathrm{ppm}-2.715 \mathrm{ppm}$ sedangkan standar normal kandungan timbal $(\mathrm{Pb})$ pada hijauan adalah maksimal 3.0 ppm. Jadi, hijauan pakan di semua desa lokasi penelitian masih aman untuk diberikan pada ternak, cemaran timbal $(\mathrm{Pb})$ dari transportasi dan industri sekitarnya tidak berdampak besar pada keamanan hijauan untuk dikonsumsi ternak, tetapi cemaran berdampak langsung pada tanah dan air di lokasi tersebut. Hijauan pakan hanya terkena dampak tidak langsung dari cemaran timbal $(\mathrm{Pb})$, biasanya terhadap kuantitas dan kualitas hijauan. Berdasarkan hasil analisis proksimat pada hijauan pakan di semua lokasi penelitian, kandungan protein kasar (PK) berkisar 4.94\% - 7.20\%, hasil ini menunjukkan kualitas hijauan di Kecamatan Citeureup sangat rendah

Tabel 4. Konsentrasi timbal (Pb) pada hijauan, tanah, dan air

\begin{tabular}{lccc}
\hline \multirow{2}{*}{ Desa } & \multicolumn{2}{c}{ Konsentrasi Timbal (Pb) (ppm) } \\
\cline { 2 - 4 } & Hijauan & Tanah & Air \\
\hline Hambalang & $0.838 \pm 0.210$ & $17.318 \pm 0.231$ & $0.03 \pm 0.009$ \\
Citeureup & $2.371 \pm 0.456$ & $25.102 \pm 0.899$ & 0.00 \\
Puspasari & $2.559 \pm 0.339$ & $16.161 \pm 0.978$ & $0.056 \pm 0.000$ \\
Puspanegara & $2.652 \pm 0.209$ & $18.387 \pm 0.521$ & $0.047 \pm 0.000$ \\
Tarikolot & $2.715 \pm 0.059$ & $15.372 \pm 0.184$ & $0.12 \pm 0.047$ \\
Karang Asem Barat & $1.439 \pm 0.270$ & $23.721 \pm 0.408$ & 0.00 \\
Karang Asem Timur & $0.539 \pm 0.188$ & $14.520 \pm 0.225$ & $0.034 \pm 0.025$ \\
\hline
\end{tabular}

\section{KESIMPULAN}

Pola penyediaan hijauan pada desa padat industri di Kecamatan Citeureup bersifat cut and carry dan potensi hijauan pada daerah tersebut pun cukup rendah. Kambing jawa merupakan jenis ternak yang dominan diternakkan karena kambing memiliki daya tahan yang kuat dan mudah beradaptasi. Desa Hambalang ketersediaan hijauan cukup baik dan bervariasi. Hal ini dikarenakan Desa Hambalang sendiri meskipun kualitas hijauannya dinilai dari kandungan nutrisinya tidak jauh beda dengan yang lainnya, namun pencemaran timbal pada hijauan lebih sedikit dibandingkan desa lainnya meskipun desa lainnya secara umum aman untuk dikonsumsi ternak dan juga ketersediaan hijauan.

\section{DAFTAR PUSTAKA}

Crowder, L.V., H.R. Chheda. 1982. Tropical Grassland Husbandry. London (GB) and New York (US) : Longman

Pairunan,AKJ, Nanere L, Arifin S.S.R., Samosir, Romadulus Teingkaisari J.R. Lalo Pua, Bachrul

Ibrahim dan Hariadi Asmadi. 1985. Dasar-Dasar Ilmu Tanah. Makasar (ID): Badan Kerjasama Perguruan Tinggi Negri Indonesia Timur.

Sinaga, S. 2009. Pertumbuhan Ternak. [internet]. [Diunduh tanggal 10 Januari 2015]. Tersedia pada http://blogs.unpad.ac.id/Sauland Sinaga 